\title{
An Ecofeminist Interpretation of Sons and Lovers*
}

\author{
Ting Bo \\ Faculty of Foreign Languages, Huaiyin Institute of Technology, 223001, Jiangsu, China
}

\begin{abstract}
D. H. Lawrence is an influential figure of the 20th century in English literature, and also one of the most controversial writer. This paper mainly analyzes Sons and Lovers from the perspective of ecofeminism, by describing nature and female's resistance and struggle of their fates, and the decline of the males, it explores the oppression of patriarchy and with the awakening of feminism gradually shakes the male consciousness of patriarchy, it criticizes the deep influence on nature and human society by industrial civilization, so it advocates the anti-industrialization and reconstructs a harmonious society. Finally it stresses the original instinct, advocates the free development of humanity and a harmonious relations between men and nature, men and society.
\end{abstract}

Index Terms—Sons and Lovers, ecofeminism, reconstruction

\section{INTRODUCTION}

It is well-known that David Herbert Lawrence was one of the greatest English novelist in the twentieth century with a repute of "one of the greatest personage history of English literature". In general, he had written a large number of works, including novels, poems and scripts. There was no doubt that he blamed the dehumanization life for the results of industrialization.

Lawrence was born in a miner family as the fourth child of Arthur John Lawrence. Apparently, his father was poor enough and always got drunk. Besides, he had a bad relation with his wife who was a former pupil teacher. Due to their poverty, she had to work in a lace factory. In his view, his mother deserved a better man instead of his father. Thus, the experience of his childhood influenced greatly on his work of creation.

Actually, Sons and Lovers was a semi-autobiographical novel. It was created in the period of the illness of his mother, so he demonstrated this novel relevant with a special maternal love. It told the story of the protagonist Paul Morel who had a close as well as deep relation with his mother, Mrs. Morel. At least he can get a special warm feeling from his mother beyond maternal love. What's more, he hated his farther so much that he was unwilling to see him. In fact, because of the despair and disappointment for Mr. Morel, Mrs. Morel put all her love into her two beloved sons. However, excessive love can make no sense. We find that her first son William unfortunately died, and her second son Paul could not love any more. While Paul had fall in love with Miriam and Clara, he still hesitated between spirit and sex. The fact was that Mrs. Morel had derived her sons rights of love. It was easier to see that the mother's love was absolutely deformed and diseased leading to the tragedy of her two sons. In the work of Sons and Lovers, the three female characters Mrs. Morel, Miriam and Clara all embodied the impacts of ecofeminism. Generally speaking, ecofeminism recently has been a popular study orientation in Sons and Lovers. Ecofeminism is the combination of women's liberation movement and the ecological movement.

From this perspective, ecofeminism is inevitably connected with our daily life, such as nature and human. Women gradually realized they are treated unfairly. Even though they have hard life in that age, they never give up and struggle for pursuing the rights of happiness. On the other hand, it symbolizes the awareness of new female. And Lawrence payed much attention to the working class, and young Paul's tragic fate has reveled class conflicts and gender issues. Undoubtedly, the development of industry has great impact on human and nature, breaking the balance of society in various aspects. Eventually, in Sons and Lovers, Paul's abnormal behaviors cause the whole tragedy. Obviously, the perspective of ecofeminism gives us a better understanding of this novel.

\section{The OpPRESSION OF PATRIARChAL SOCIETY}

Ecofeminism links natural domination and gender domination, and points out that the origin of this domination is patriarchy. The patriarchal concept occurred originally as an anthropological and sociology. The definition of patriarchy is the family pattern that men who have ruled rights dominate all the members of the family. Based on this point, patriarchy apparently became the root of oppression for nature and women. In Sons and Lovers, as we can see, the pits appeared all over the countryside, some of which had been made queer mounds and little black places and finally polluted and formed the environment of the village of Bestwood. The houses which miners lived seemed very decent

\footnotetext{
* Fund project: An Ecofeminist Study on D.H. Lawrence’s Novels commissioned by Jiangsu Education Department (Project No.:2017SJB1629)
} 
and stable, unexpectedly, were filled with ash-pits.

It not only brought the passive role of nature but also weakened the power of females. In many ways, males and females were treated unequally. From this novel, in Mrs. Morel's view, she did not want the third child because of the despair of life. She used to be alone and despised her husband, but she could not live without him. Sometimes she was tied of this poverty and meaningless life. Historically, Mr. Morel was the head of all powers, especially he swilled himself drunk and did nothing, showing that Mrs. Morel was accustomed to being oppressed by her husband. It was very easy to see that they have accepted the phenomenon unconsciously. In a male-dominated society, all the authoritative rights belonged to men in the fields of politics, economy, law, religion, education, military. The greatest inequality in human society was the inequality between the genders. Male power was made as an invisible hand, which made Mrs. Morel and the village disadvantaged and subordinate.

\section{A. Nature's Subdued Role}

From the perspective of nature, it has its own charm and powerful internal value. In the long period, there used to be wooded hills and mountains, including lush forest, unique geological structure. However, nature in patriarchal society was subdued and obedient. In this novel, coal mines, as a non-renewable resource, was wanton acquisition. We found that Paul's working environment was so terrible, furthermore, as a miner, Mr. Morel had to stay in the small mines. The actual conditions of living in the Bottoms, that was so well built and that looked so nice, were quite unsavoury because people must live in the kitchen, and the kitchens opened on to that nasty alley of ash-pits. And all the villages were in a mess with same pits just like ants into the earth. Thus, the village of Bestwood was formed by these different black mines. To be honest, the contrast of environment had uncovered the difference of nature in patriarchy.

At the beginning of the novel, we know Bestwood is at its beast a mining village with rows of bungalows as its original name "Hell Row" suggests. We are more likely to imagine the dominating color of such a place is black and gray. Contrary to the common thought, we are occasionally overwhelmed by the beauty exhibited between the lines as we go deeper into the book. The front gardens give the humble miners' dwellings its liveliness. It is in the front garden that Lawrence displays his fantastic botanical knowledge of flowers and that Mrs. Morel and young Paul seeks their consolation. (Zhang, 2014: 13)

The natural environment of mankind had become the object of plunder, conquest and devastation. When Paul first found a job in a factory, the surroundings were so terrible. All the lights came from downwards and the ground floor was always night, moreover, the second floor was rather gloomy. That's to show Paul's work place was dark and insanitary which had been badly damaged, leading to the binary opposition between civilization and nature. Every time he had to come back to this unsatisfactory space without fresh air. Therefore, in the face of nature, human beings were acting on the natural world and creating an increasingly rich material wealth for themselves with unprecedented scale and speed. When the human beings are satisfied with their achievements, they have tasted the bitter fruits of human centralism. At the same time, mankind has become the slave of industrial civilization by blindly pursuing material wealth.

\section{B. Male's Paramount Domination}

When it comes to male's domination, we usually think of the word of patriarchy. Traditionally, male plays a strong role with an absolute power in society. Patriarchy is linked with institutionalized control rather than individual sexism. The reason why female is regarded as domestic character while male is a role of outside one is to reiterate the subordination of woman in a patriarchal society. Actually, female is not recognized for many rights and suffers discrimination and oppression. They are treated as a subordinate of men. No matter in east or west, male domination always exists. The essence of male chauvinism is personal oppression of natural relationships.

At the same time, Mr. Morel, Paul's father in Sons and Lovers, who was only an illiterate miner marries a well-educated middle class woman, while they had different backgrounds and values, they still loved each other at first and fell in love quickly. Especially after marriage, Mrs. Morel had to surrender him. From this point, it was simple to understand that patriarchy offered an advantage to fathers with complete possession of family power. Women, no matter how ambitious and talented they are, are customarily confined to the domestic housework and are not allowed to work outside. (Ma, 2012) Even if Mrs. Morel had a well background and maybe can live a better a life with another guy, but she eventually chose Mr. Morel and became Mrs. Morel, she still could not divorce and be a housewife at home with no wish.

Besides, females and nature were both dominated by males in different aspects. In man's view, they were the king of family, and everything was up to them. For instance, Mr. Morel thought that the house was his not their collective one. He just said with a word of "mine." In other words, in most male's mind, they earned more money than females so they had privilege to abuse and scold their wife and children. In the history of patriarchy, females took serious duty to bear and bring up children. They should obey male thoroughly. The second female character Miriam, who had the similar case. Miriam was always set at nought by her brothers and refused to be approached, so at the beginning she held aloof to Paul. Last and most importantly, she still wanted to marry Paul while he would not take her. As regarded to Clara, Paul thought she was a married woman and would not suit him. In fact, it was a blatant discrimination and domination against women. 


\section{Female's Submissive Status}

Although marriage is what you make of it, females are in passive situation in patriarchy. Truly, pains and griefs exist in marriage, but for these females who lived in Victorian era were completely submissive. They had few rights. Despite they were one of members of family, as a matter of fact, they were sacrifices of their husbands.

It is a fact that Mrs. Morel's obedience was another representation. When Mr. Morel got drunk and quarreled with her, she still came back home. He even called her the word of "ussy" and ignored that she was his unique wife who used every energy for the whole family. They even could not sit and talk peacefully, and the house which they lived in did not belong to them and they had owed a lot of money. When she knew the fact, she just sat there, bitter and indignant. Could not divorce, she continued her disappointed life. Nevertheless, she knew him too well and felt lonely, the faith in life was shaken. To some extent, women had no right so that they ended a miserable marriage in patriarchy. It was fine for women to take care of their family, but it was definitely not a good idea to divorce because they can only depend on their husband and suffer the oppression. What's worse, women were lack of economic status.

Besides, with the traditional customs and moral principles, women were forced to be silent about their rights. Comparing with Mrs. Morel, Miriam was also another slave of patriarchy. Everyday the only thing she can do is to prepare housework and accept abuse. Actually, Miriam was very cautious about the surrounding environment. At home she tried her best to do the housework and wanted to be respected. As we all know, the most painful thing was losing oneself in the process of loving someone too much. Bur for these poor women, they had no choice but to continue in the situation. What's worse, Paul was so cruel at Miriam' religious belief which made her sad and disappointed. Miriam was astonished and painful when Paul once said their love was only friendship. She was hurt deeply but still waited for Paul's return. It was believed that women in Sons and Lovers were sometimes stepped with Paul. To sum up, destiny is not a matter of chance, but it is a matter of choice; and it is not a thing to be waited for, but it is a thing to be achieved.

\section{The Unbalance OF Destructed Society}

The novel was set before the first world war in England. Capitalist industrial civilization was just like a double-edged sword, bringing material satisfaction to the human, but making negative effects. The whole social environment and social atmosphere were bad. The capitalist industrial civilization caused the workers' misfortune, cruelty of capitalist exploitation. (Li, Guo, 2016) Lawrence revealed a stark reality to readers in Sons and Lovers. In the novel, Lawrence not only described the unbalance of natural ecology, but also provided his insight into the dislocated spiritual ecology of people.

Lawrence showed the reader directly the capitalist industrial civilization linked with environmental damage. The working conditions of miners were so bad as well as dirty that miners became rude and preferred to choose alcohol to relax themselves and forgot the current trouble and poverty. People started and ended with family, but in this novel, family seemed to be a prison which bounded the whole life of Mrs. Morel. It was hard for Mrs. Morel to imagine that her favorite little son killed her with his own hands. It is not incomprehensible at all to say that this state is an exhaustive unbalance of humanity. Meanwhile, males gradually lost certain believes and tended to be on the decline of their positions. Correspondingly, females seemed to understand themselves better and not afraid of male like before, this time they got more confidence on dealing with affection.

\section{A. Ravage of the Nature}

It goes without saying that industrialization is the period of social and economic change that transforms a human group from an agrarian society into an industrial society, involving the extensive re-organisation of an economy for the purpose of manufacturing. There is no denying that this kind of social revolution results in the destruction of nature.

In Sons and Lovers, as what had been described, the idyllic landscape had been destroyed by the ruthless and dirty coal mines. And donkeys were used to carry these mines, together with odd black places were formed as their homes. The disgust of the serious consequences of environmental degradation caused by people blindly pursuing money. Although "Hell Row" was burned down by a big fire, new mines were ready to sink and new companies planned to operate again. Furthermore, factory life with its enforced confinement and long working hours isolated men from the natural world that was his true connection to the life force. Flowers, water, and other natural images are identified with sensuality and beauty, while the mines bury the fields in dust and darkness.

Therefore, nature was the dominant of that age. In this novel, it is understandable that the lower class do not benefit from industrialization, just like Mr. Morel who had suffered the tragic life. Machines had become important in industry, that's why Mr. Morel worked hard but earned little. All these caused the unbalanced situation of society. As for others, like the pot man who would call this village the word of "flamin and scrattlin", they were the existence of nature, and they must rely on the nature though deeply destructed. Simply, nature's unbalanced destruction was a real problem. In many cases, however, people in this novel violated natural rules and interfered with natural process which destroyed natural beauty and ecological balance, such as the air, the river, the forest and etc. Deforestation and ecological balance had been severely damaged. In other words, nature was in serious condition for their own natural revenge.

\section{B. Decline of the Males}

The destructive power of industrial civilization had an influence on men. The important role for male in life produces 
a chain of reaction, especially for male spirits. Actually, males in the Sons and Lovers were gradually in a decline state.

Mr. Morel was a classic character who did not enjoy a valuable life. In his family, nobody cared this poor man any more even his children. It seemed that he was an invisible man in front of his wife and children. Males like Mr. Morel always worked in a hard surrounding and made little money. Besides, he almost lost the joy of life and only used alcohol to numb himself. And he abused Mrs. Morel after getting drunk. The misfortune of Mrs. Morel actually revealed the decline of male's life. Not only did Mrs. Morel not mold him into what she expected but also destroyed him. In this marriage, he was a loser, an absolutely loser that his wife had to turn to their children for comfort. This was an inevitable as a decline of the males.

As for Paul, he admired her mom very much, but in his mind and action, he dared not to love any girl and feared to disappoint his mother. Although he loved his mother, he hated himself for his love. It can be concluded that the root of Paul's inner struggle was his male-dominated consciousness and also the awakening of feminism. But after his mother died, Paul felt sad. On the surface, Paul's inner conflict was intimate or alienated.

When he fell in love with Miriam, he never thought Miriam would pitied him. Whereas she despised him because he was blown about by any wind of authority and could not make a decision for himself. Every time Paul walked with Miriam, the only sense was bitter with biting his lips and clenched fists. Once he thought of Miriam, he had a feeling of guilty of his mother. In addition, for another female character Clara, Paul could not defeat his inner voice. In his eyes, he looked paltry and insignificant, unlike Clara's husband Dawes. At least Dawes dared to admit his failure and was a real man. Paul was almost destroyed and shamed to continue his life.

\section{RECONSTRUCTION OF HARMONIOUS SOCIETY}

Because of the industrial revolution, the whole society had been in a mess. However, there definitely were better ways to arouse people's awareness of conserving. On the contrary, the nature was under great wreck. Males and females were in an unfair world. In Lawrence's view, he was in favor of sex liberation and against any violation of instinct. What's more, he advocated the equality of bisexual relations. Thus, from this part, it's very important to find the origin of nature and explore the real value of lives. From Sons and Lovers, it was rather easy to notice that Mr. Morel and Mrs. Morel were unhappy in their marriage, and their problem was that both of them had discrimination on genders. They couldn't respect each other and wanted too much. Obviously, women had the same rights as men, there was no difference between male and female. So did Paul's relationships with Miriam and Clara. If they all believed love can win everything, how could they lost love so easily. Overall, the value is that everything in nature is equal, we human beings should respect it, not just only for its usage. In order to reconstruct a harmonious society, it is essential to protect the environment around us.

\section{A. Respect for the Nature}

It should be acknowledged that natural respect will be a difficult process as the industrialization has been deep-rooted for thousands of years. As the improvement of technology, more and more people argue that they can control the nature. The power of nature is unpredictable. Once nature is out of control, human beings may suffer the result.

In this novel, to some degree, nature can make some differences. For example, when Mrs. Morel quarreled with Mr. Morel, the beautiful outside scenery gave her a great encouragement to stand up and keep on the unfortunate life. She began to forget everything and make the children first. Under this circumstance, the distorted love between Paul and his mother arose spontaneously.

It's necessary to treat nature with a respectful attitude. We are part of nature, and we can not live without nature. Once nature is under destruction, human is the victim. Paul enjoyed the wonderful life in the Willey Farm and soon made friends with the boys. It was nature's power that Miriam was not afraid of the religious intensity and stood again to love Paul. In Lawrence's eyes, spirit, flesh and the nature are a unified whole. And the nature plays a leading role according to its super strength, which controls our spirits and flesh, and determines the occurrence and development of everything. ( Zhang, 2010) As we may find when Paul had a feeling with Clara, the shadowy land began to take life, the leaves turned distinct with a lovely beach. Everything in nature seemed so nice and dynamic, and love was produced a magic energy. However, when his mother Mrs. Morel died, the opposite was the case. Paul felt everything had gone smashed, the last painting he drew was the day of his mother. Nothing was left, the street was empty, when the first snow dropped, they did not mean anything to him. But they were something that could motivate his motion. Only the black night was his home and he could put himself in it. It's necessary to make great efforts and protect our home-the earth. So it's our responsibility to respect and return to nature.

\section{B. Self-recognition of the Males}

In regard to recognition for the males, they should have a correct self-awareness. The death of William and Paul's two failure love relations showed this point. Both of them could not realize their true value and only surrounded with their mother. As for William, he could have had an ideal job and a beautiful wife, however, he was too well-behaved to go against Mrs. Morel. Without any hesitation, he should tell his mother the real idea and follow his own heart. Unfortunately, it finally caused the sad ending of the story. And William died with no expectation.

Thus, Paul soon became the next wretched guy. It's likely that Paul's deepest love ruined the peaceful and normal life, 
and he thought his love belonged to his mother. He could not learn to love himself and others, and the only goal of life is his mother. After Mrs. Morel died, Paul almost destroyed himself. His despair of life went after with his mother, the dependence of love suddenly collapsed as a substantial wall. Hence, both William and Paul were supposed to have a proper way towards their special love. Moreover, Mr. Morel had the same destiny. He lost hope for life and just wanted to get drunk, maybe the unique way to forget every annoyance and trouble. Mrs. Morel was so accustomed to Mr.Morel's crude behaviors for many years that she even won't talk about it. In that age, men had more advantages in social and economic status, while women were weak because of their natural conditions. Nevertheless, Mr. Morel did not fully take the advantages, in contrast, he preferred to complain about the plight. Because of work issues, Mr. Morel slammed the door and let her pregnant wife outside. A real man must take the responsibility of the family instead of being a passive one. The couple lived in a disharmonious family which produced negative impact on children.

\section{Reverence for the Females}

Basically, the harmonious relations between men and nature or men and women are related to the reverence of the females. In the novel, the second female character, Miriam, only wanted spiritual love but escaped from Paul's sexual need. For a long time, the impassive Christianity let more people dare not to touch the topic of sex. Apart from avoidance, they often preyed in religion. But she argued that love should not be based on sexuality as it may violate the doctrine. Nonetheless, Paul wanted more than spirit, he still liked her body. For these reasons, people should have a correct attitude towards females, they are not sacrifice of sexuality for males, and males should respect females with a reverent attitude.

In terms of Clara, Paul believed that he belonged to nobody, in particular Clara. He at one time thought that she was a married woman who could be a barrier for their love relation. Actually, Clara had her own opinion and was an independent lady. She had her own job and did not depend on her husband financially. From her perspective, even though she got married, she could choose to get away her husband as he was unfaithful to her. As a woman in patriarchy, unlike Mrs. Morel and Miriam, Clara had more freedom in making choice and against the unfair restraint by males. Then she gradually realized that she never fully had him and never got the essence of his real idea. Paul only wanted her flesh and love-making, which was opposite to Clara's need. Thus, after the struggle of love, she finally left Paul and decided to come back to her husband. It was also a symbol of independent flesh. The reason why Paul could not gain the last happiness was that he divided love into soul and flesh. Not only should humans seek the equality relationship between males and females but also pursue a self-liberation.

\section{REFERENCES}

[1] Banerjee, Arup. (2003). The Cambridge Edition of D. H. Lawrence's Letters. Taylor journal, (3): 231-238.

[2] Chen, Ling. (2014). Ecological Criticism Based on Social Gender: The Basic Principles of Ecofeminism. CSCanada, (1): 67-72.

[3] Du, Jingiie. (2016). A Study on the Conversational Implicature in Sons and Lovers From the Perspective of Cooperative Principle. CSCanada, (5): 85-90.

[4] Fu, Xiaofang. (2015). Analysis of the Female Images in Sons and Lovers from the Feminist Perspective. Read and Write Periodical, (4): 1-2.

[5] Hu, Jiayi, Fan, Lijuan. (2016). An Analysis on Paul's Emotional Experience with Freud's Psychoanalytical Theory in Sons and Lovers. Harbin Normal University, (27): 249-250.

[6] Lawrence, D. Herbert. (1994). Sons and Lovers. Beijing: Foreign Language Teaching and Research Press.

[7] Li, Haiyan, Weng, Rongqian, Guo, Xiaojun. (2016). Paul Morel's Oedipus Complex in Sons and Lovers, CSCanada, (1): $28-32$.

[8] Luo, Dimin. (2013). Code Switching in Sons and Lovers. Scientific Research Publishing, (4): 39-42.

[9] Newton, Julianne Lutz, Sullivan, C. William. (2005). Nature, Culture, and Civil Society. Taylor Journal, (3): 195-209.

[10] Norton, Christine Lynn. (2012). Social work and the environment: An Ecosocial Approach. Wiley Journal, (21): 299-308.

Ting Bo was born in Jiangsu, China in 1980. She got the MA of Arts at East China Normal University, China in 2009. She was currently a lecturer in Faculty of Foreign Languages in Huaiyin Institute of Technology, Jiangsu, China. Her research interest is literature, intercultural communication, teaching method. 